JIIP: JURNAL ILMIAH ILMU PEMERINTAHAN

Vol.6, No. 1, 2021

DOI: 10.14710/jiip.v6i1.8965

\title{
Menangkal Politik Identitas: Analisis Kemenangan HT-Zadi pada Pemilihan Bupati Kepulauan Sula Tahun 2015
}

\author{
Sahrul Pora ${ }^{1}$, Zuly Qodir ${ }^{2}$, Titin Purwaningsih ${ }^{3}$ \\ 1,2,3 Magister Ilmu Pemerintahan, Universitas Muhammadiyah Yogyakarta
}

Dikirimkan: 17 September 2020 Direvisi: 22 Januari $2021 \quad$ Diterbitkan: 25 Maret 2021

\begin{abstract}
INTISARI
Pascareformasi, pemilihan kepala daerah di Indonesia selalu diwarnai dengan penggunaan isu politik identitas. Isu ini sengaja dilakukan agar dapat mempengaruhi perilaku politik masyarakat mayoritas yang memiliki kesamaan identitas dengan sang kandidat, baik itu agama maupun etnis. Adapun penelitian ini menggunakan metode kualitatif dengan pendekatan studi kasus. Penulis menggunakan metode kualitatif dengan tujuan untuk mengetahui bagaimana Hendrata Thes dan Zulfahri Abdullah (selanjutnya HT-Zadi) bisa tampil sebagai pemenang, padahal agama dan etnisitas Hendrata Thes merupakan minoritas di kabupaten Kepulauan Sula. Tujuan dari penelitian ini adalah untuk mengungkap faktor-faktor yang mempengaruhi kemenangan HT-Zadi. Hasil penelitian menyimpulkan bahwa terpilihnya Hendrata Thes dan Zulfahri Abdullah karena terdapat beberapa strategi yang digunakan mulai dari membentuk tim yang solid dan kuat di setiap desa, door to door dan kampanye melalui media sosial. Faktor lain yang juga mempengaruhi karena efek dari pemerintahan masa lalu yang belum bisa memenuhi janji politiknya. Untuk menangkal isu politik identitas yang sangat masif yang digunakan oleh lawan politiknya, para tim sukses beserta kandidat meyakinkan para pemilih dengan programprogram unggulan HT-Zadi baik di bidang ekonomi, pendidikan, kesehatan dan lain sebagainya yang akan diimplementasikan jika mereka terpilih.
\end{abstract}

\section{KATA KUNCl}

pilkada; politik identitas, strategi, Kepulauan Sula

\section{Pendahuluan}

Indonesia merupakan salah satu negara yang menggunakan sistem demokrasi. Demokrasi dalam pengertian yang klasik adalah suatu pemerintahan dengan kekuasaan berada di tangan rakyat. Maksud dari pengertian tersebut adalah Pemerintah sebagai representasi dari negara, dalam menjalankan kekuasaannya harus mendapatkan persetujuan dari rakyat, karena rakyat merupakan pemegang kedaulatan tertinggi sebagaimana yang telah dijelaskan dalam UUD 1995. Menurut Oktavia \& Widagdo (2019), demokrasi sebagai dasar dari kehidupan bernegara memiliki pengertian bahwa,

Korespodensi:

Magister Ilmu Pemerintahan, Universitas Muhammadiyah Yogyakarta, Jl. Brawijaya, Geblagan, Tamantirto, Kec. Kasihan, Bantul, Daerah Istimewa Yogyakarta 55183.

Email: sahrulpora28@gmail.com 
pemerintah dalam membuat suatu kebijakan harus melalui masukan dari masyarakat termasuk memberikan penilaian atas kebijakan yang dibuat, karena kebijakan tersebut akan sangat menentukan kehidupan masyarakat. Sedangkan menurut Suyatno (2016), bentuk dari demokratisasi seharusnya menempatkan masyarakat pada tempat yang sesungguhnya dalam memilih pemimpin. Terdapat kekuasaan politik dari masyarakat untuk menentukan siapa yang harus memilih mereka melalui prosedur pemilihan umum. Selanjutnya menurut Qodir \& Latief (2015), Setidaknya Terdapat tiga prinsip utama yang mencerminkan proses politik menuju peradaban demokrasi, yakni: kebebasan, kesetaraan dan toleransi. Apabila tiga prinsip tersebut tidak ada dalam proses politik yang sedang berlangsung, maka proses politik tersebut masih jauh dari makna demokrasi yang sesungguhnya.

Salah satu wujud dari praktik demokrasi ditingkat daerah adalah dilaksanakan pemilihan kepala daerah secara langsung. Pemilihan kepala daerah merupakan implementasi dari kekuasaan rakyat untuk memilih kepala daerah secara langsung dengan prinsip jujur, bebas rahasia dan adil (D. Lestari, 2019). Pelaksanaan pilkada seharusnya dilaksanakan secara demokratis, karena pilkada yang demokratis akan menguatkan demokrasi di Indonesia (Sutrisno, 2017). Namun dalam pelaksanaan pilkada di Indonesia masih sering diwarnai dengan penggunaan isu-isu seperti etnis, agama, ras dan golongan untuk kepentingan politik sebagian kelompok yang justru mencederai nilai-nilai dari demokrasi itu sendiri. Penggunaan isu SARA dalam proses politik tersebut seringkali dikenal dengan istilah politik identitas. Politik identitas menurut Alfaqi (2016), adalah Suatu alat politik yang digunakan oleh kelompok tertentu dalam hal kesamaan etnis, budaya, agama dan yang lainnya, dengan maksud untuk memberikan perlawanan politik atau dijadikan sebagai kekuatan politik untuk menampilkan jati diri dari suatu kelompok tersebut. Pendapat yang senada juga disampaikan oleh Kiftiyah (2019), bahwa politik identitas adalah salah satu cara politis yang mendahulukan kepentingan suatu kelompok yang memiliki kesamaan identitas baik dari aspek agama, ideologi, ras, etnis, dan gender. Politik identitas pada dasarnya adalah penyatuan kelompok yang memiliki kesaamaan identitas karena adanya ketidak adilan dan ketidak puasan. Selanjutnya (Adiwilaga, TR, \& Mustofa, 2017) menjelaskan bahwa, bahkan politik identitas seringkali menjadi alasan dari suatu kelompok untuk membangun sebuah gerakan dengan maksud untuk menekan pemerintah agar bisa memenuhi tuntutan-tuntutan yang menjadi kepentingan identitasnya.

Menurut Mubarok (2018), Politik identitas menjadi suatu masalah bagi negara yang beragam seperti Indonesia karena beberapa hal berikut. Pertama, politik identitas sangat berpotensi untuk mengecilkan bahkan menghilangkan identitas lain yang hidup di tengah masyarakat. kedua, politik identitas kurang memberikan ruang pada perdebatan yang bekualitas soal program kerja, melaikan masyarakat diharuskan untuk memilih atas dasar kesamaan identitas. Ketiga, politik identitas lebih sering memecah belah masyarakat ketimbang menyatukan. (Y. S. Lestari, 2018) juga menjelaskan bahwa, 
perpecahan yang selalu terjadi selama ini karena dilatar belakangi oleh pengelompokan politik atas dasar identitas tertentu, sehingga stabilitas negara terganggu yang ditandai dengan krisis kepercayaan publik kepada pemerintah, terbatasnya ruang demokrasi, hingga penyebaran hoax. Pendapat yang hampir sama juga disampaikan oleh Dhani (2019), penggunaan politik identitas sebagai salah satu cara untuk mendapatkan dukungan dari pemilih justru menciptakan perpecahan antara masyarakat, sistem demokrasi yang tidak sehat, serta buruknya pendidikan politik untuk rakyat dan institusi partai politik.

Dalam beberapa penelitian terdahulu menjelaskan bahwa pengaruh politik identitas dalam pelaksanan pilkada di Indonesia masih sangat kuat. Temuan dari D. Lestari (2019) menjelaskan Kemenangan Anis-Sandi pada pelaksanaan pilkada DKI 2017 menunjukkan bahwa, politik identitas berhasil dijadikan sebagai isu untuk mempengaruhi pilihan politik dari para pemilih agar memberikan pilihan politiknya pada calon yang memiliki kesamaan identitas. Pendapat yang sama juga disampaikan oleh Kurniawati (2017), adanya penggunaan politik identitas oleh para pendukung Anis-Sandi sehingga pasangan Ahok-Djarot bisa kalah karena latar belakang etnis Ahok yang merupakan Tionghoa dan beragama Kristiani. Temuan selanjutnya diperkuat oleh Nasrudin \& Nurdin (2018), hasil dari proses pilkada DKI 2018-2022 menunjukkan bahwa pengaruh politik identitas dalam proses demokrasi sangat kuat. Menurut Syuhudi (2016), politik identitas yang terjadi di Kota Manado, selalu ada maksud tersembunyi bagi para kelompoknya dalam memenuhi kepentingan politik mereka, baik dalam aspek kekuasaan politik maupun ekonomi. Identitas ini sudah terbentuk sejak awal reformasi dan melahirkan beberapa identitas yakni: Brigade Manguni Indonesia, Legium Christum, Laskar Manguni, Makapetor dan Milisi Waraney.

Sebagaimana juga yang terjadi di Kota Sorong menurut Snanfi, Darwin, \& Ikhwan (2018), politik identitas etnis digunakan untuk meraih kekuasaan politik di Kota Sorong. Politik identitas etnik dimanfaatkan sebagai kekuatan politik dalah hal perebuatan kekuasaan pada pemilihan kepala daerah. Dalam penelitian lainnya oleh Faraidiany, Kusmanto, \& Warjio (2019), di Sumatera Utara politik identitas dibangun melaui iklan politik oleh pasangan Djarot Saiful Hidayat dan Sihar Sitorus. Isu politik identitas sengaja dimainkan untuk menaikkan dukungan dari publik Sumatra Utara. Sama halnya yang terjadi di Kalimantan Barat menurut Kristianus (2016), isu politik identitas dalam politik lokal di Kalimantan Barat masih sangat kuat. Politik identitas tersebut melibatkan dua etnis asli terbesar yakni Dayak dan Melayu. Temuan yang sama juga terjadi pada pemilihan kepala daerah di Kota Makasar tahun 2013 sebagaimana menurut Syaf (2017), komunikasi politik untuk menggalang kekuatan etnis dibangun melalui berbagai media cetak, media sosial, organisasi kekerabatan etnis, serta kampanye hitam. Narasi yang selalu di produksi adalah kami " $100 \%$ asli Makasar dan dia bukan Makasar". Demikian juga pada pemilihan kepala daerah di kota Tebing Tinggi tahun 2017 menurut Saleh, Yuslim, \& Rosyidi (2018), terdapat mayoritas penduduk Kota Tebing sebagai 
masyarakat lokal yang menginginkan agar kepala daerah yang terpilih harus berasal dari penduduk asli kota Tebing Tinggi.

Penelitian selanjutnya menurut Salim (2015) politik identitas etnis di Maluku Utara selalu diproduksi untuk meraih dukungan politik dari kelompok etnisnya. Tampilnya kekuatan identitas etnis pada pilkada Maluku Utara sehingga secara berlahan-lahan mengeser kekuatan elit kesultanan dan birokrat yang selama ini sudah sangat dominan. Penjelasan tersebut diperkuat oleh temuan dari Sweinstani \& Hasanah (2017) dalam pelaksanaan pilkada di Maluku Utara isu politik identitas masih sangat kuat. Narasi tentang memilih putra daerah menjadi sangat intens dilakukan. Selanjutnya menurut Maksum (2019), penggunaan isu agama dalam pilkada di kabupaten Pulau Morotai adalah sesuatu hal yang tidak bisa dihindarkan. Hal tersebut tidak terlepas dari kondisi kehidupan masyarakat Morotai yang masih sangat kental dengan sentimen agama, sehingga isu ini selalu digunakan untuk mendapatkan dukungan dari para pemilih. Dalam aspek agama menurut Al Qurtuby (2018), ketika suharto tak lagi berkuasa dan indonesia masuk pada jaman reformsi, politisasi agama yang terlalu berlebihan sering dilakukan, sehingga berdampak buruk pada kehidupan bernegara bahkan antar agama.

Sangat berbeda sebagaimana yang terjadi dalam temuan-temuan sebelumnya tentang kuatnya pengaruh politik identitas dalam pilkada, kabupaten Kepulauan Sula merupakan salah satu kabupaten yang mempunyai seorang bupati dengan latar belakang etnis Tionghoa dan beragama non-Muslim. Pada pilkada tahun 2015 yang diikuti oleh tiga pasangan calon yakni: Rusmin Latara-Saleh Marasabesi, Hendrata ThesZulfahri Abdullah dan Safih Pauwah-Faruk Bahnan memberikan hasil yang sangat berbeda. Safi Pauwah yang Sebelumnya menjabat sebagai wakil bupati periode 2010-2015, diperkirakan akan memenangkan pertarungan ini karna memiliki mesin politiknya yang cukup solid. Disisi yang lain beliau merupakan petahana yang memiliki popularitas sangat baik dimata public, namun ternyata mampu dikalahkan oleh Hendrata Thes yang berpasangan dengan Zulfahri Abdullah. Menariknya, Hendrata Thes merupakan kaum minoritas di kabupaten Kepulauan Sula. Dikatakan kaum minoritas karena beliau merupakan keturunan Tionghoa dan beragama non-Muslim, sedangkan mayoritas masyarakat Kepulauan Sula adalah berlatar belakang agama Islam.

Dengan demikian, penelitian ini akan menjelaskan lebih mendalam terkait dengan bagaimana Hendrata Theis dan Zulfahri Abdullah mampu tampil sebagai pemenang pada pilkada kabupaten Kepulauan Sula tahun 2015. Padahal isu SARA terus menerus dimunculkan dari awal proses pilkada sampai pada hari pemilihan suara. Isu ini terus diproduksi oleh lawan politik dengan tujuan untuk menjatuhkan pasangan Hendrata Theis dan Zulfahri Abdullah, karena Hendrata Thes merupakan turunan Tionghoa dan beragama non-Muslim.

Penelitian ini menggunakan metode kualitatif dengan jenis penelitian studi kasus. Penelitian kualitatif merupakan suatu penelitian yang ditujukan untuk mendeskripsikan 
dan menganalisa fenomena, peristiwa, aktivitas sosial, sikap, kepercayaan, persepsi, pikiran individu maupun kelompok. Beberapa deskripsi digunakan untuk menemukan prinsip-prinsip dan penjelasan yang menuju pada pengambilan suatu kesimpulan (Bachri, 2010). Penelitian kualitatif mengembangkan bermacam-macam motode yang saling memiliki keterkaitan sehingga diharapkan dapat mengembangkan pemahaman atas suatu permasalahan yang sedang dihadapi.

Berkaitan dengan penelitian ini penulis akan menjelaskan bagaimana Hendrata Thes dan Zulfahri Abdullah bisa keluar sebagai pemenang dalam pilkada kabupaten Kepulauan Sula tahun 2015. Teknik pengumpulan data dalam penelitian ini menggunakan wawancara dan beberapa dokumen yang sesuai dengan kebutuhan penelitian. Dalam proses wawancara, peneliti menanyakan beberapa hal terkait dengan bagaimana strategi dan tantangan-tantangan yang ditemukan dalam upaya untuk memenangkan HT-Zadi serta bagaimana mereka bisa menangkal isu politik identitas yang sangat masif digunakan oleh lawan politik. Terdapat lima informan yang penulis wawancarai dalam penelitian ini. Segagian data wawancara tersebut kemudian diolah menggunakan aplikasi Nvivo12 plus, yang bertujuan untuk mengetahui tingkat intensitas antara variabel.

\section{Pengaruh Politiilk Identitas Pada Pilkada Kabupaten Kepulauan Sula}

Penduduk kabupaten Kepulauan Sula terdiri dari berbagai macam jenis suku, antara lain suku Sula, Button, Wakatobi, Bajo, Bugis, Jawa, Sumatera dan lain lain. Dan suku yang terbanyak diantara suku-suku terebut adalah suku Sula, karena merupakan suku asli di kabupaten Kepulauan Sula. Pada Pemilihan kepala daerah di kabupaten Kepulauan Sula pada tahun 2015, mempunyai cerita tersendiri. Hal tersebut karena salah satu kandidat merupakan turunan Tionghoa dan berlatar belakang agama non-Muslim namun berhasil menang sebagai bupati periode 2015-2020. Kemenangan tersebut tentu terdengar sangat aneh, karena etnis Tionghoa di kabupaten Kepulauan Sula sangatlah sedikit, dan juga masyarakat Kepulauan Sula mayoritas beragama muslim.

Tabel 1. Jumlah penduduk kabupaten kepulauan sula berdasarkan agama

\begin{tabular}{|c|l|r|c|}
\hline No & \multicolumn{1}{|c|}{ Agama } & Jumlah masyarakat & Persentase \\
\hline 1 & Islam & 189.023 & $96,93 \%$ \\
\hline 2 & Katolik & 571 & $0,29 \%$ \\
\hline 3 & Kristen & 5386 & $2,76 \%$ \\
\hline 4 & Lainnya & 4 & $0,00 \%$ \\
\hline \multicolumn{2}{|c|}{ Total Penduduk } & 195,023 & $99,98 \%$ \\
\hline
\end{tabular}

Sumber: BPS Kabupaten Kepulauan Sula 
Dari tabel diatas menunjukkan bahwa presentase agama diluar dari agama Islam hanyalah 3\%, sehingga sangatlah wajar jika politisasi agama bisa terjadi. Sebagaimana menurut Putra, Pengunaan politik identitas sebagai strategi untuk meraih tujuan tertentu masih sangat relevan untuk digunakan pada negara Indonesia. Hal tersebut dianggap wajar, karena dalam demokrasi siapa pun pemenangnya sangat ditentukan oleh suara mayoritas (Putra, 2019). Kehadiran politik identitas dalam kontestasi politik electoral di Indonesia bukanlah sesuatu yang aneh, karena Indonesia dihuni oleh berbagai macam masyarakat dengan latar belakang etnis, budaya, pandangan, agama, yang berbeda-beda (Adiwilaga et al., 2017). Dalam pertarungan politik electoral, berbagai macam cara akan dilakukan bukan hanya untuk memenangkan hati pemilih, tetapi juga untuk menjatuhkan lawan politik dengan cara menyebarkan isu-isu yang dapat mempengaruhi pilihan politik para pemilih. Demikan juga yang terjadi pada pemilihan kepala daerah kabupaten Kepulauan Sula tahun 2015.

Persaingan tersebut diwarnai dengan penyebaran isu SARA terhadap pasangan calon Hendrata Thes dan Zulfahri Abdullah. Isu SARA yang sangat masif di sebarkan adalah terkait dengan etnis dan agama. Hal tersebut sengaja dilakukan agar masyarakat tidak memilih Hendrata Thes karna beliau bukanlah seorang muslim dan memiliki latar belakang sebagai etnis Tionghoa. Serangan dengan menggunakan isu SARA yang dialamatkan kepada Hendrata Thes tersebut banyak digunakan melalui Facebook, dan diskusi dari mulut ke mulut. Penyebaran isu tersebut kemudian sangat berdampak pada keharmonisan masyarakat yang hidup berdampingan satu dengan yang lainnya. Pada alasan yang lain, dalam Sejarah kepemimpinan bupati dan wakil bupati Kepulauan Sula pada dua periode sebelumnya, adalah mereka yang semuanya berlatar belakang agama Islam dan etnis Sula. Narasi yang selalu dibangun untuk mempengaruhi perilaku politik para pemilih terhadap Hendrata Thes yaitu: "jangan memilih pemimpin yang berlatar belakang berbeda dan sebaiknya memilih pemimpin yang muslim". Meskipun isu SARA terus digunakan untuk menjatuhkan pasangan Hendrata Thes dan Zulfahri Abdullah, namun nyatanya tidak berhasil mempengaruhi para pemilih secara signifikan sehingga pasangan ini berhasil keluar sebagai pemenang pada pilkada Kepulauan Sula tahun 2015.

Terpilihnya beliau sebagai bupati Kepulauan Sula menunjukkan bahwa faktor agama maupun etnis bukanlah satu-satunya penentu kemenangan pada pemilihan kepala daerah. Pendapat tersebut bisa dibenarkan, karena sudah ada beberapa daerah seperti Kalimantan Barat yang gubernur nya dari non-Muslim sedangkan mayoritas penduduk Kalimantan Barat beragama Islam, kemudian Maluku yang mayoritas 
masyarakatnya beragama non-Muslim tetapi gubernurnya beragama Islam dan bupati Banjar Negara yang merupakan etnis Tionghoa (Nasir, 2017.). Akan tetapi dari beberapa daerah tersebut relatif memiliki jumlah pemeluk agama yang tidak jauh berbeda dengan pemeluk agama lainnya, sedangkan di kabupaten Kepulauan Sula bupati yang terpilih dari non-Muslim dan mayoritas masyarakat beragama muslim. Di sisi yang lain beliau memiliki latar belakang sebagai etnis Tionghoa sedangkan Tionghoa adalah etnis terkecil di kabupaten Kepulauan Sula. Namun harus diakui, kemenangan Hendrata Thes tersebut juga karena berpasangan dengan Zulfahri Abdullah yang merupakan putra asli dari Kepulauan Sula dan beragama islam. Dengan alasan tersebut sehingga isu SARA yang selalu dimainkan oleh lawat politik bisa sedikit diminimalisir. Di sisi yang lain, Zulfahri Abdullah sebelum mencalonkan diri sebagai Wakil Bupati beliau merupakan anggota DPRD Provinsi Maluku Utara yang sudah terpilih selama dua periode. Jadi sudah pasti beliau memiliki basis masa yang telah terbentuk sebelumnya. Sehingga ketika dipasangkan, keduanya bisa melengkapi satu sama lain.

\section{Strategi yang digunakan oleh HT-Zadi.}

Pemilihan kepala daerah atau disebut pilkada, menjadi momentum bagi setiap calon kepala daerah, tim sukses beserta partai politik untuk menarik dukungan dari masyarakat dengan cara melempar isu-isu yang menjadi kebutuhan masyarakat, sehingga pada nantinya akan bertindak sebagai pemberi solusi atas isu-isu yang telah berkembang tersebut. Kemenangan politik berkaitan erat dengan sejauh mana kandidat atau kontestan politik berhasil merebut hati rakyat melalui program kerja yang ditawarkan agar mereka dapat memenangkan suatu pertarungan electoral. Visi dan misi dari calon kepala daerah harus bersentuhan langsung dengan kebutuhan masyarakat sehingga, masyarakat akan memilihnya sebagai seorang kepala daerah.

Menurut penjelasan dari para narasumber, langkah pertama yang dilakukan untuk mengetahui kecenderungan masyarakat dalam memilih kepala daerah di kabupaten Kepulauan Sula yaitu dengan menggunakan beberapa hasil survey yang dilakukan oleh tim (survey internal). Survey tersebut dilakukan untuk mengukur sejauh mana respon publik terhadap kandidat Hendrata Thes dan Zulfahri Abdulah, sehingga bisa di ketahui alasan-alasan masyarakat tidak mau memilih mereka. hasil survey tersebut selanjutnya dibedah dan kemudian seluruh tim digerakkan untuk mencari tau motivasi apa sehingga masyarakat tidak mau memilih HT-Zadi lalu tim mencari solusi yang terbaik untuk menyelesaikan masalah tersebut. 


\section{Gambar 1. Strategi Tim HT-ZADI}

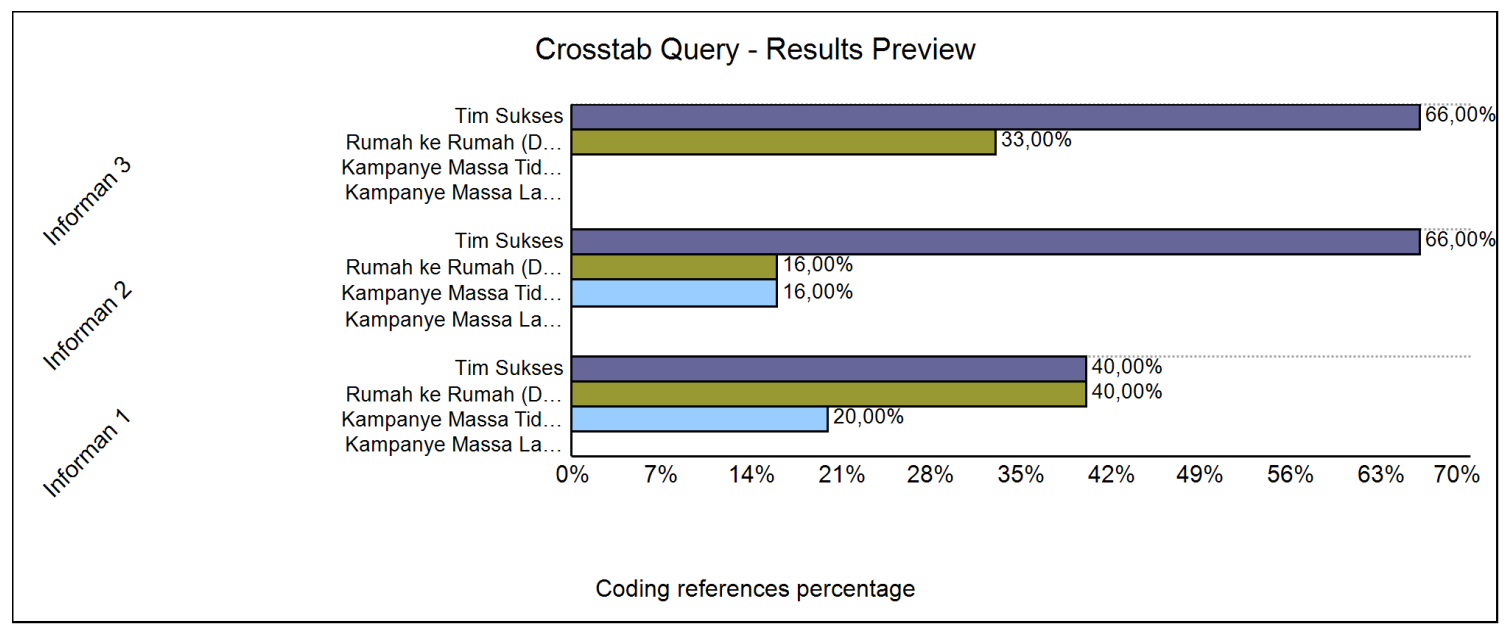

Sumber: Hasil Analisa Nvivo12 plus

Masalah-masalah yang ditemukan sesuai dengan hasil survey adalah berkaitan dengan latar belakang agama Hendrata Thes yang merupakan seorang Kristiani dan etnis Tionghoa. Melalui masalah yang ditemukan melalui survey tersebut yang selanjutnya menjadi dasar dari tim HT-ZADI untuk merumuskan strategi. Sebagaimana hasil analisa diatas menurut beberapa informan, terdapat beberapa strategi yang digunakan untuk meyakinkan publik sehingga Hendrata Thes dan Zulfahri Abdullah berhasil menang sebagai bupati dan wakil bupati kabupaten Kepulauan Sula tahun 2015. Faktor yang sangat kuat dalam mempengaruhi kemenangan HT-Zadi yaitu dibentuk tim sukses yang solid, kuat dan bisa kerja mulai dari tingkat kabupaten hingga ke desa sebagaimana keterangan gambar diatas Tim sukses yang terbentuk ditingkat kabupaten banyak di isi oleh para politisi-politisi senior yang sudah lama terlibat dalam kehidupan politik, baik sebagai anggota DPRD dan pengurus partai politik. Sebagimana Julfi Umasanagdji yang merupakan ketua tim pemenangan, saat itu juga berposisi sebagai anggota DPRD Kepulauan Sula dari fraksi partai Demokrat. Sedangkan tim sukses yang berada di tingkat desa di isi oleh para tokoh masyarakat dan tokoh agama. Tim-tim yang telah dibentuk kemudian digerakkan untuk meyakinkan masyarakat dengan mensosialisasikan seluruh program unggulan HT-Zadi mulai dari pendidikan, kesehatan, ekonomi dan lain sebagainya. Karena para tim sukses tersebut adalah mereka yang punya pengaruh disetiap desa Sehingga dalam mensosialisasikan HT-Zadi beserta program kerja mereka akan dengan mudah diterima oleh masyarakat setempat. Cara lain yang juga memiliki pengaruh yang cukup besar terhadap kemenangan HT-Zadi adalah dengan cara door to door atau masuk rumah keluar rumah. Cara ini dilakukan sebagai upaya untuk mengetahui secara langsung apa yang menjadi kebutuhan dari masyarakat sehingga nantinya akan dioleh menjadi program yang akan dilaksanakan jika HT-Zadi terpilih sebagai bupati dan wakil bupati tahun 2015. Door to door di akui cukup 
efektif karena seluruh tim sukses bisa berinteraksi secara langsung dengan masyrakat sehingga segala keinginan dari masyarakat terhadap HT-Zadi dapat diketahui. Melalui cara ini juga seluruh tim dapat menjawab apa yang menjadi keraguan masyarakat terhadap HT-Zadi, sehingga dengan mudah bisa mencari solusi untuk menjawab keraguan tersebut. Door to dorr juga dilakukan oleh tim sukses untuk memberikan pemahaman yang baik kepada masyarakat tentang bagaimana memilih kepala daerah tampa harus mempertimbangkan aspek suku dan agama.

Beberapa strategi yang digunakan oleh tim HT-Zadi tersebut sebagai upaya untuk menjawab persoalan-persoalan yang ditemukan oleh tim sesuai dengan hasil survey. Mengandalkan orang-orang yang memiliki pengaruh cukup besar disetiap desa tentunya sangat dilatar belakangi oleh agama dan etnis Hendrata Thes yang merupakan kelompok minoritas di Kepulauan Sula. Harus diakui, faktor agama dan etnis dalam pemilihan kepala daerah dalam beberapa kasus sangat mempengaruhi kemenangan seorang kandidat. Apalagi jika kandidat tersebut ikut mencalonkan diri di daerah yang dalam aspek agama maupun etnis merupakan kelompok mayoritas. Sehingga dengan memasukkan orang-orang penting (tokoh agama dan adat) di setiap desa kedalam tim, diyakini dapat mempengarusi perilaku politik masyarakat Kepulauan Sula tehadap Hendrata Thes agar tidak lagi mempersoalkan latar belakang agama dan etnis untuk menentukan pilihan politik. Disisi yang lain popularitas Hendrata Thes yang masih sangat minim karena beliau merupakan pendatang baru dalam dunia politik, sehingga melalui orang-orang tersebut diyakini dapat dengan mudah untuk mensosialisasikan Hendrata Thes.

Sedangkan kampanye masa tidak langsung yaitu berupa penggunaan media sosial untuk sarana sosialisasi politik sebagaimana biasanya digunakan pada beberapa daerah lainnya di Indonesia, ternyata tidak terlalu memiliki pengaruh yang signifikan jika dibandingkan dengan dua cara lainnya yaitu pembentukan tim sukses yang solid dan door to door. Media sosial tidak memberikan pengaruh yang besar pada pelaksanaan pilkada Kepulauan Sula, sehingga cara tersebut tidak terlalu menjadi prioritas tim HTZadi. Hal tersebut dianggap wajar, karena sebagian masyarakat kabupaten Kepulauan Sula masih belum tersentuh oleh media sosial. Faktor lain yang diakui juga ikut memberikan pengaruh pada kemenangan Hendrata Thes dan Zulfahri Abdullah sebagaimana yang disampaikan oleh ketua tim pemenang HT-Zadi yaitu karena efek dari pemerintahan masa lalu. Kemenangan Hendrata Thes dan Zulfahri Abdullah karena sebagian besar rakyat sudah tidak percaya dengan pemerintahan masa lalu yang cenderung hanya menghamburkan janji namun minim bukti, sehingga ekspresi itulah yang kemudian diwujudkan oleh rakyat dengan memilih Hendrata Thes dan Zulfahri Abdullah. Perlu diketahui, dua calon yang lain yakni Safi Pauwah dan Rusmin Latara 
merupakan politisi lama yang rekam jejak mereka sudah dikenal oleh masyarakat Kepulauan Sula.

Tabel 2. Presentase Suara Pemilihan Kepala Daerah Kepulauan Sula Tahun 2015

\begin{tabular}{|l|l|l|l|}
\hline No & Pasangan calon & Jumlah Suara & Presentase \\
\hline 1 & $\begin{array}{l}\text { Rusmin Latara dan Ir. H. M. } \\
\text { Saleh Marasabessy, M. Si }\end{array}$ & 11.161 & $24,78 \%$ \\
\hline 2 & $\begin{array}{l}\text { Hendrata Thes, S. Pd.k dan } \\
\text { Zulfahri Abdullah, S. Ik }\end{array}$ & 18.017 & $37,78 \%$ \\
\hline 3 & $\begin{array}{l}\text { H.Safi Pauwah, SH dan H. Faruk } \\
\text { Bahanan }\end{array}$ & 17.848 & $37,43 \%$ \\
\hline \multicolumn{2}{|l|}{ Total suara sah } & 47.683 & $99,36 \%$ \\
\hline \multicolumn{2}{|l|}{ partisipara suara pemilih } & 309 & $0,64 \%$ \\
\hline \multicolumn{2}{|l|}{ Pemilih terdaftar } & 47.992 & $72,75 \%$ \\
\hline
\end{tabular}

Sumber: KPU Kabupaten Kepulauan Sula

Sesuai dengan hasil perolehan suara sebagaimana keterangan tabel diatas menunjukkan bahwa, Hendrata Thes dan Zulfahri Abdullah berhasil menang sebagai Bupati dan Wakil Bupati Kabupaten Kepulauan Sula periode 2015-2020 dengan perolehan suara $37,59 \%$. Meskipun perolehan suara HT-Zadi tidak signifikan jikalau dibandingkan dengan perolehan suara dari pasangan nomor urut 3 yaitu Safi Pauwah dan Faruk Bahnan, namun kemenangan tersebut sangatlah luar biasa. Hal tersebut karena 2 pasangan calon lainnya memiliki latar belakang sebagai muslim dan juga Safi Pauwah merupakan petahana, yang pada periode sebelumnya menjabat sebagai wakil bupati. Komitmen perubahan yang ditawarkan HT-Zadi kepada masyrakat Kabupaten Kepulauan Sula sehingga masyarakat tidak memperdulikan latar belakang agama maupun etnis dalam menentukan pilihan politik. Kemenangan tersebut bisa dimaknai sebagai bentuk kesadaran politik masyarakat dalam memilih pemimpin dengan mengacu pada komitmen perubahan yang ditawarkan oleh para kandidat tampa harus mempersoalkan status agama maupun etnisnya.

Kesadaran tersebut bukanlah murni kerena faktor komitmen perubahan dengan hanya melihat pada program yang lebih baik dari pasangan HT-Zadi, melainkan juga ikut dipengaruhi oleh kekecewaan masyarakat terhadap petahana yang dianggap tidak mampu membangun Kepulauan Sula diperiode sebelumnya menjadi lebih maju. 


\section{Kendala Tim saat Mensosialisasikan HT-Zadi}

Meskipun memiliki tim yang solid serta strategi yang matang namun tetap saja ada beberapa kendala yang di temukan oleh tim saat mensosialisasikan HT-Zadi sebagaimana keterangan dari para narasumber.

\section{Gambar 2. Kendala-Kendala Saat Mensosialisasikan HT-Zadi}

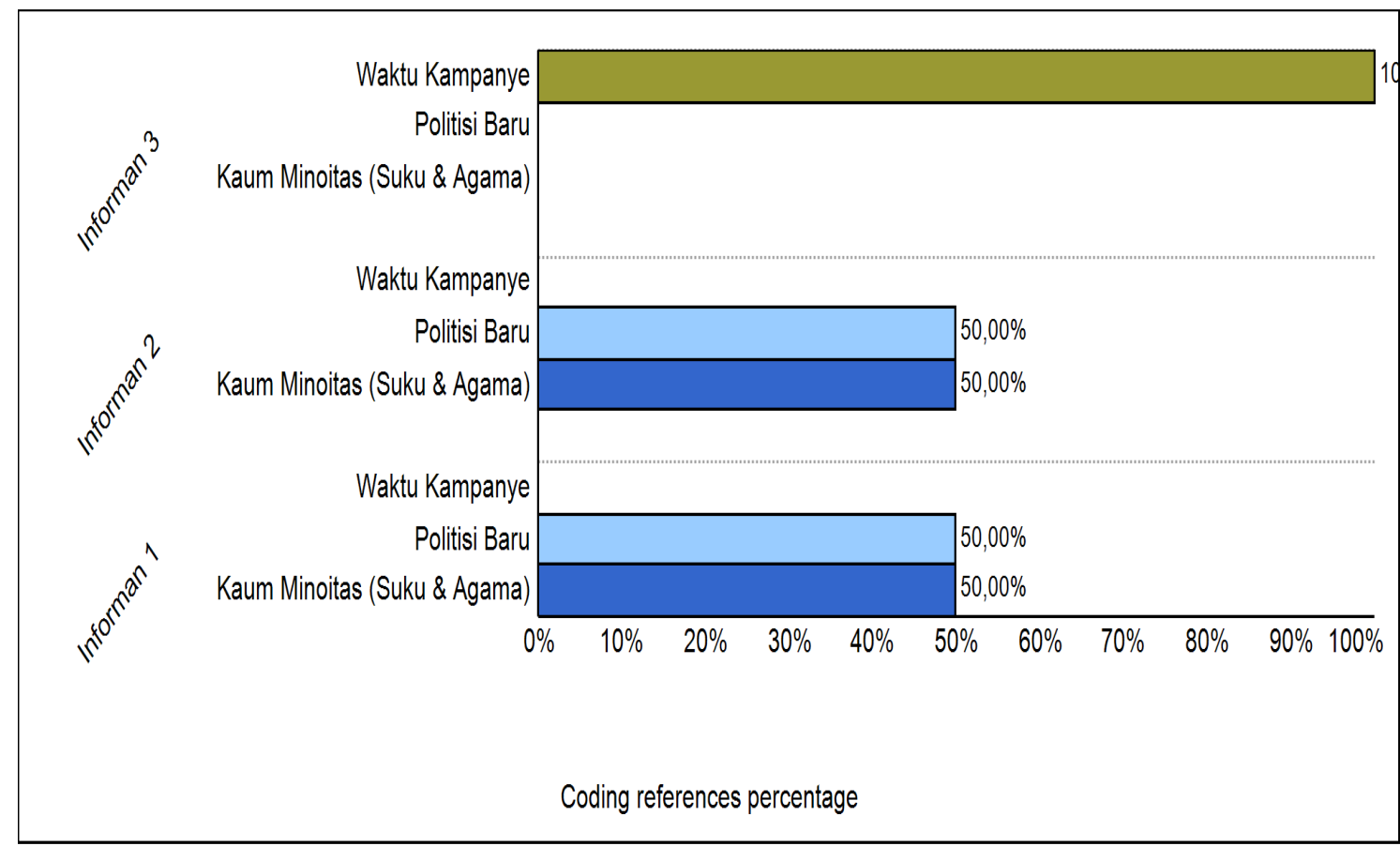

Sumber: Hasil Analisis Nvivo12 plus

Berdasarkan hasil coding diatas, terdapat beberapa kendala selama mensosialisasikan Hendrata Thes dan Zulfahri Abdullah kepada masyarakat. Kendalakendala tersebut meliputi waktu kampanye yang sangat singkat, Hendrata Thes adalah pendatang baru di dunia politik dan latar belakang agama maupun etnis Hendrata Thes yang merupakan minoritas di kabupaten Kepulauan Sula. Perlu diketahui Hendrata Thes merupakan politisi baru yang pada tahun 2015 mencalonkan diri sebagai bupati kabupaten Kepulauan Sula.

Secara popularitas, Hendrata Thes masih kalah jauh jika dibandingkan dengan dua bakal calon lainnya yang sudah lama berkiprah di dunia politik Kepulauan Sula. Karena beliau merupakan politisi baru, sehingga seluruh tim sukses di perintahkan untuk bekerja semaksimal mungkin dengan berbagai cara agar publik dapat mengenal sosok Hendrata Thes

Faktor etnis dan agama juga ikut menjadi kendala dalam hal mensosialisasikan figur Hendtara Thes. Fanatisme masyarakat Sula terhadap agama Islam yang sudah sangat kuat, sehingga tim sukses harus meyakinkan dengan narasi "Kita memilih pemimpin daerah bukan pemimpin agama". Di sisi yang lain karna beliau merupakan turunan Tionghoa sedangkan mayoritas masyarakat di Kepulauan Sula adalah etnis Sula, 
turut menjadi kendala yang cukup berarti. Kendala tersebut bisa dianggap wajar, karena beberapa kasus pemilihan kepala daerah di Indonesia memperlihatkan kecenderungan kandidat dengan latar belakang sebagai minoritas ketika berhadapan dengan kelompok mayoritas pasti akan kalah. Namun dengan komitmen perubahan yang ditawarkan oleh Hendrata Thes, membuat sebagian besar masyarakat Kepulauan Sula tidak lagi menjadikan faktor etnis dan agama sebagai alasan utama untuk menentukan pilihan politik Wacana perubahahan yang di maksud adalah dengan menyedorkan beberapa program stategis dari Tim HT-Zadi kepada masyarakat.

Kegagalan petahana dalam membangun kepulauan Sula pada periode sebelumnya turut diwacanakan oleh tim ketika mengkampanyekan HT-Zadi. Isu tersebut digunakan agar dapat meyakinkan masyarakat untuk tidak memilih petahana dan lebih memberikan pilihan politik kepada HT-Zadi. Melalui wacana perubahan dengan menyodorkan beberapa program stategis untuk membangun kabupaten Kepulauan Sula, baik di bidang ekonomi, pendidikan, kesehatan dan yang lainya, dapat meyakinkan masyarakat untuk memilih HT-Zadi ketimbang dua kandidat yang lain.

\section{Peran Partai PKS dalam Mengelola Isu SARA}

Kampanye pada pemilihan kepala daerah merupakan ajang bagi tim sukses maupun para kandidat untuk berkomunikasi secara langsung dengan pemilih. Isi pesan yang disampaikan dalam komunikasi tersebut adalah untuk mengajak para pemilih agar memilih kandidat yang mereka inginkan. Tentu penggiringan opini dengan menggunakan isu sara akan dilakukan dalam kampanye mereka. Isu SARA sengaja dilakukan untuk mengajak masyarakat agar memilih calon kepala daerah yang masih memiliki kesamaan identitas baik suku maupun agama. Hal ini semakin mempertegas bahwa penggunaan isu SARA dalam pemilihan kepala daerah selalu digunakan, apalagi jika kandidat yang lainnya memiliki latar belakang suku maupun agama yang berbeda dan merupakan kaum minoritas di daerah tersebut.

Partai PKS sebagai salah satu partai politik dengan basis masa Islam, berkoalisi dengan partai Demokrat dalam mendukung Hendrata Thes dan Zulfahri Abdullah pada Pilkada Kepulauan Sula tahun 2015. Koalisi tersebut diyakini bisa terjadi karna Zulfahri Abdullah sebagai calon wakil bupati merupakan ketua dewan pengurus cabang partai PKS kabupaten Kepulauan Sula.

Gambar III. Koalisi Partai Politik Pada Pilkada Kepulauan Sula 2015

\begin{tabular}{|l|l|l|l|}
\hline No urut & $\begin{array}{l}\text { Pasangan calon bupati dan wakil } \\
\text { bupati }\end{array}$ & Koalisi partai politik \\
\hline 1 & $\begin{array}{l}\text { Rusmil Latara dan Saleh } \\
\text { Marasabessy }\end{array}$ & PDI, PAN dan PKPI \\
\hline 2 & $\begin{array}{l}\text { Hendrata Thes dan Zulfahri } \\
\text { Abdullah }\end{array}$ & Demokrat, PKS dan PKB \\
\hline
\end{tabular}




\begin{tabular}{|l|l|l|}
\hline 3 & Safi Pauah dan Faruk Bahnan & Gerindra, PPP, dan PBB \\
\hline
\end{tabular}

Sumber: KPU Kabupaten Kepulauan Sula

Pilkada merupakan arena untuk melaksanakan peran dan strategi partai politik dengan sebaik-baik mungkin, tujuannya adalah untuk memenangkan setiap pertarungan politik electoral. Partai Keadilan Sejahtera yang berkoalisi dengan beberapa partai politik lainnya dalam mengusung Hendrata Thes dan Zulfahri Abdullah, memiliki hasrat yang sangat kuat untuk bisa keluar sebagai pemenang. Sebagai partai Islam yang ikut mengusung salah satu kandidat yang beragama non-Muslim, tentunya akan memiliki tugas tersendiri dalam meyakinkan publik agar memilih kandidat yang mereka usung tersebut. Peran Partai dimulai dari pemetaan medan hingga merumuskan konsep gerakan untuk mengelola isu yang beredar di masyarakat. Hal ini dilakukan agar bisa meraih dukungan masyarakat, dan mengimbangi strategi lawan politik. Sebagaimana petikan wawancara bersama Zulfahri Abdullas selaku ketua DPD PKS kepulauan sula dibawah ini:

\footnotetext{
“...Adanya Isu SARA dalam pilkada di Kabupaten Kepulauan Sula pada tahun 2015, Karena salah satu calon bupati yakni, bapak Hendrata Thes berlatar belakang agama minoritas (kristen). Jadi isu SARA sengaja dimunculkan baik itu dari partai politik maupun tim sukses lawan politik untuk menurunkan popularitas calon Hendrata Thes. Dan untuk menyikapi gejolak dari isu tersebut, partai menggerakkan peran para kader-kader untuk menyakinkan masyarakat sula Supaya agar jangan terprofokasi dengan isu SARA dalam pilkada, dan mengajak masyarakat saling menjaga persatuan dan kesatuan antara sesama. Adapun peran partai Keadilan Sejahtera dalam mengelola isu SARA, yang jelas peran partai secara struktural mulai dari para kader, alim ulama, ustad, yang berada ditataran partai Terutama dalam hal meredam isu agama. Kalau di antargolongan atau suku yang lebih berperan penting ialah tokoh-tokoh masyarakat terutam Tokoh adat. Dari situlah peran partai keadilan sejahtera sangatlah penting untuk menangkal isu sara yang beredar di masyarakat" (wawancara penulis, 1 Agustus 2017).
}

Isu SARA sengaja dimainkan oleh lawan politik untuk mempengaruhi perilaku pemilih dari umat Islam, agar tidak memilih Hendrata Thes karena beliau beragama nonMuslim dan turunan Tionghoa. Oleh karna itu Partai Keadilan Sejahtera menyikapi gejolak isu SARA tersebut dengan memaksimalkan peran dari para kader yang berada di tataran partai untuk memberikan pemahaman pendidikan politik yang baik agar masyarakat menjadi dewasa dalam berpolitik sehingga saling menjaga antara sesama umat beragama yang hidup berdampingan dalam kehidupan sehari-hari, serta meyakinkan masyarakat agar tidak mudah terpancing oleh sikap permusuhan primodialisme yang sempit. Para tokoh agama, tokoh masyarakat dan tokoh adat yang berada dijajaran partai dikerahkan untuk memberikan pemahaman kepada masyarakat kabupaten Kepulauan Sula agar memilih pemimpin bukan atas faktor agama namun lebih kepada komitmen calon kepala daerah untuk membuat perubahan. 
Isu SARA yang selalu digunakan oleh lawan politik untuk menyerang kandidat HTZadi, dilawan dengan wacana "kita memilih kepala daerah bukan pemimpin agama". Melalui tokoh-tokoh agama dijajaran partai yang turut dilibatkan dalam mensosialisasikan HT-Zadi dengan maksud agar dapat menepis isu SARA yang selalu digunakan oleh lawan politik. Wacana tersebut karena dikembangkan oleh partai Islam melalui tokoh-tokoh agama pula, tentu akan sangat mempengaruhi perilaku politik masyarakat yang lebih cenderung menggunakan faktor agama dalam menentukan pilihan politik. Selanjutnya adalah hasil wawancara penulis dengan kabid humas DPC PKS Kepulauan Sula sebagaimana di bawah ini:

\footnotetext{
"Isu SARA adalah isu global, apabila sudah dikonsumsi oleh publik apalagi kaitannya dengan keyakinan seseorang (agama), khususnya pada pemilihan bupati dan wakil wupati abupaten Kepulauan Sula tahun 2015. Yang jelas isu SARA merupakan grendesain lawan politik. Ketika isu ini dimainkan merupakan satu hal yang cukup buruk. Apabila terjadinya benturan antara pendukung pro dan kontra pasangan calon yang rugi yaitu masyarakat lokal bukan yang lain atau dari luar, dan juga dampak pada suara pasangan calon. Dan peran partai keadilan sejahtera dalam mengelola isu sara Yaitu melakukan kegiatan-kegiatan politik lainnya untuk meyakinkan publik bahwa sosok bapak Zulfahri adalah putra asli daerah dalam mendampingi bapak Hendrata Thes sebagai pasangan calon"(wawancara penulis, 28 juli 2017).
}

Dalam pertarungan politik electoral jika isu SARA dijadikan sebagai alat politik untuk menjatuhkan lawan politik, maka isu tersebut akan menjadi isu publik karena akan dikonsumsi oleh seluruh masyarakat. Sebagaimana yang terjadi di kabupaten Kepulauan Sula, isu SARA sengaja diproduksi oleh lawan politik agar masyarakat tidak memilih Hendrata Thes yang berasal dari minoritas baik dari sisi etnis maupun agama. Sehingga Partai Keadilah Sejahtera sebagai salah satu partai partai pendukung melakukan berbagai macam kegiatan politik untuk memberikan keyakinan kepada masyarakat Sula agar memilih Hendrata Thes dan Zulfahri Abdullah. Apalagi sosok Zulfahri Abdullah merupakan putra asli Kepulauan Sula sehingga isu tersebut bisa ditepis.

Zulfahri Abdullah dipasangkan dengan Hedrata Thes diyakini sebagai upaya untuk dapat menepis isu SARA yang sangat masif digunakan oleh lawan politik. Dengan hadirnya beliau untuk mendampingi Hendrata Thes sebagai wakil bupati, akan dapat meyakinkan masyarakat Kepulauan Sula bahwa ada representasi dari etnis Sula dan Agama Islam sehingga tidak lagi mempersoalkan faktor agama dan etnis dari Hendtara Thes. Apalagi beliau merupakan politisi lama yang sudah pernah menjadi anggota DPRD selama dua periode, sehingga tentu memiliki basis pendukung yang cukup banyak pula.

\section{Penutup}

Pelaksanaan pemilihan kepala daerah yang selalu diwarnai dengan penyebaran isu-isu seperti etnis, agama, ras, golongan untuk kepentingan politik dari sekelompok orang selalu terjadi di Indonesia dari pemilu ke pemilu baik ditingkat pusat hingga daerah. Hal tersebut dianggap wajar karena negara Indonesia dihuni oleh berbagai 
macam masyarakat dengan latar belakang etnis, budaya, pandangan, dan agama yang berbeda-beda, sehingga ketika isu ini dimunculkan sudah pasti akan memiliki dampak yang besar terhadap pilihan politik para pemilih. Apalagi dalam kontestasi politik electoral tersebut terdapat kandidat yang dalam aspek agama maupun etnis merupakan minoritas di daerah tersebut, maka besar kemungkinan isu ini akan bekerja dengan baik. Pada pelaksanaan pilkada 2015 terdapat salah satu kandidat yang berasal dari kelompok minoritas baik dari aspek agama dan etnis di kabupaten kepulauan sula. Meskipun berasal dari kelompok minoritas, namun beliau bisa terpilih sebagai bupati pada periode 2015-2020. Kemenangan tersebut terdengar sangat aneh sebab dua kandidat lainnya adalah masyarakat asli sula dan beragama islam. Ditambah lagi salah satu kandidat nomor urut 3 yakni H. Safi Pauwah merupakan petahana kerena enjabat sebagai wakil bupati pada periode sebelumnya dan ikut berdarung kembali pada pilkada 2015.

Berbagai macam cara digunakan oleh tim sukses maupun pendukung untuk meyakinkan masyarakat gar memilih Hendtata Thes dan Zulfahri Abdullah tampa harus mempersoalkan latar belakang agama dan etnis dari Hendrata Thes. Strategi yang digunakan yaitu dibentuk tim sukses yang solid, kuat dan bisa kerja mulai dari tingkat kabupaten hingga ke desa. Kemudian door to door atau masuk rumah keluar rumah. Cara ini dilakukan untuk mengetahui secara langsung apa yang menjadi kebutuhan dari masyarakat sehingga nantinya akan dioleh menjadi program yang akan dilaksanakan jika HT-Zadi terpilih sebagai bupati dan wakil bupati tahun 2015. Partai PKS sebagai sebagai salah satu partai yang basis masanya dari kalangan umat Islam memiliki peran tersendiri dalam menepis segala isu sara yang dimainkan oleh para lawan politik. Seluruh kader dalam jajaran struktural baik tokoh agama dan tokoh masyarakat digerakkan untuk memberikan pendidikan politik yang baik kepada publik dalam hal memilih pemimpin tampa harus mempersoalkan latar belakang dari calon kepala daerah tersebut. Sedangkan faktor lain yang ikut mempengaruhi kemenangan Hendara Theis dan Zulfahri Abdulah yaitu karena adanya keinginan dari masyarakat untuk membuat perubahan. Kepemimpinan masa lalu yang banyak memberikan janji tanpa bukti sehingga ekspresi kekecewaan tersebut diwujudkan dengan memilih Hendrata Thes dan Zulfahri Abdullah sebagai bupati dan wakil bupati periode 2015-2020

\section{Ucapan Terima Kasih}

Penulis mengucapkan terima kasih kepada seluruh informan yang berkenan diwawancarai dalam penelitian ini.

\section{Pendanaan}

Penulis tidak menerima bantuan pembiayaan untuk penelitian, kepenulisan (authorship), dan publikasi dari pihak manapun.

Daftar Pustaka

Adiwilaga, R., TR, M. R., \& Mustofa, M. U. (2017). Pemilu dan Keniscayaan Politik 
Identitas Etnis di Indonesia: Sebuah Tinjauan Teoritis. POLITIKIDENTITAS.

Al Qurtuby, S. (2018). Sejarah Politik Politisasi Agama dan Dampaknya di Indonesia. MAARIF, 13(2), 43-54.

Alfaqi, M. Z. (2016). Memahami Indonesia melalui prespektif nasionalisme, politik identitas, serta solidaritas. Jurnal Ilmiah Pendidikan Pancasila Dan Kewarganegaraan, 28(2).

Bachri, B. S. (2010). Meyakinkan validitas data melalui triangulasi pada penelitian kualitatif. Jurnal Teknologi Pendidikan, 10(1), 46-62.

Dhani, F. W. (2019). Komunikasi Politik Berbasis Politik Identitas Dalam Kampanye Pilkada. Metacommunication: Journal of Communication Studies, 4(1), 143-157.

Faraidiany, M., Kusmanto, H., \& Warjio, W. (2019). Politik Identitas dalam Iklan Politik pada Pemilihan Kepala Daerah Sumatera Utara 2018. JUPIIS: JURNAL PENDIDIKAN ILMU-ILMU SOSIAL, 11(1), 113-120.

Kiftiyah, A. (2019). Upaya Rekonsiliasi Politik Identitas Pasca Pelaksanaan Pemilu 2019 di Indonesia. Jurnal Analis Kebijakan, 3(1).

Kristianus. (2016). Politik dan Strategi Budaya Etnik dalam Pilkada Serentak di Kalimantan Barat. Politik Indonesia: Indonesian Political Science Review, 1(1), 87. https://doi.org/10.15294/jpi.v1i1.9182

Kurniawati, A. I. (2017). Politik Identitas: Pertarungan Etnis Tionghoa dengan Masyarakat Muslim di Pilkada DKI Jakarta Tahun 2017, 1-13.

Lestari, D. (2019). Pilkada DKI Jakarta 2017: Dinamika Politik Identitas di Indonesia. JUPE: Jurnal Pendidikan Mandala, 4(4), 12-16.

Lestari, Y. S. (2018). Politik Identitas Di Indonesia: Antara Nasionalisme Dan Agama. Journal of Politics and Policy, 1(1), 19-30.

Maksum, A. M. (2019). Malaysian Context on Consolidation of Democracy. Konfrontasi: Jurnal Kultural, Ekonomi Dan Perubahan Sosial, 2(2).

Mubarok, H. (2018). Demokrasi, Politik Identitas, Dan Kohesi Sosial. Jurnal Bimas Islam, 11(2), 365-400.

Nasir, M. (2017). Nilai Moralitas dalam Sistem Syura (Suatu Model Sistem Politik Berdasarkan Hadis). Al-Ulum: Jurnal Studi Islam, 18(1), 1-18.

Nasrudin, J., \& Nurdin, A. A. (2018). Politik Identitas dan Representasi Politik (Studi Kasus pada Pilkada DKI Periode 2018-2022). Jurnal Studi Agama-Agama, 1(1), 34-47.

Oktavia, N., \& Widagdo, H. D. (2019). Politik Identitas: Konstruksi Pemikiran Amy Gutmann dalam Menyikapi Pesta Politik Tahun 2019. Mudra Jurnal Seni Budaya, 9(26). https://doi.org/10.31091/mudra.v34i2.707

Putra, D. K. (2019). Relevansi Politik Identitas Pemilih Muslim Dalam Pemilihan Gubernur Sumatra Utara Tahun 2018. Jurnal Antropologi: Isu-Isu Sosial Budaya, 21(2), 236244.

Qodir, Z., \& Latief, S. (2015). Kelangsungan dan Perlawanan Politik Identitas dalam Bingkai Keadaban Demokrasi. Jurnal Studi Pemerintahan, 2(1).

Saleh, M., Yuslim, \& Rosyidi, B. (2018). Politik Identitas Etnis Dalam Pemilihan Kepala 
Daerah Studi Kasus: Peranan Etnis Tionghoa Dalam Pilkada Kota Tebing Tinggi Tahun 2017, 1(14), 63-65. https://doi.org/10.15900/j.cnki.zylf1995.2018.02.001

Salim, K. (2015). Politik Identitas di Maluku Utara Identity Politic in Maluku Utara. Jurnal Kajian Politik Dan Masalah Pembangunan, 11(02), 1667-1678.

Snanfi, F. L., Darwin, M., \& Ikhwan, H. (2018). Politik Identitas Etnik Asli Papua Berkontestasi dalam Pemilihan Kepala Daerah di Kota Sorong. Sosiohumaniora, 20(2), 122-131.

Sutrisno, C. (2017). Partisipasi Warga Negara dalam Pilkada. Jurnal Pancasila Dan Kewarganegaraan, 2(2).

Suyatno. (2016). Pemilihan Kepala Daerah (Pilkada) dan Tantangan Demokrasi Lokal di Indonesia. Politik Indonesia: Indonesian Political Science Review, 1, 212-230.

Sweinstani, M. K. D., \& Hasanah, R. U. (2017). Integrasi Nasional dan Ekslusionaris Identitas dalam Pilkada 2017: Studi Kasus Pilkada Maluku Utara, DKI Jakarta, dan Kalimantan Barat. POLITIKIDENTITAS.

Syaf, E. J. (2017). Pertarungan Simbol Identitas Etnis Sebagai Komunikasi Politik Dalam Pilkada Kota Makassar. KAREBA: Jurnal Ilmu Komunikasi, 215-224.

Syuhudi, M. I. (2016). Geliat Politik Identitas di Kota Manado. Harmoni, 15(2), 56-66.

\section{Daftar Narasumber}

Hendrate Thes (Informan 1), bupati kabupaten Kepulauan Sula, 10 Agustus 2017,pukul 10.00 WIT.

Julfi Umasangadji (Infroman 2), ketua Tim Pemenang HT-Zadi, 10 Agustus 2017, pukul 21.00 WIT.

Basri Makeang (Informan 3), kekretaris Tim Pemenang HT-Zadi, 13 Agusus 2017, pukul 20.00 WIT

Zulfahri Abdullah (Informan 4), ketua DPC partai PKS kabupaten Kepulauan Sula, 1 Agustus 2017

Agung wijaya Adi Putra (Informan 5), kabid Humas PKS kabupaten Kepulauan Sula, 28 Juli 2017

\section{Tentang Penulis}

Sahrul Pora adalah Mahasiswa Magister Ilmu Pemerintahan, Universitas Muhammadiyah Yogyakarta.

Titin Purwaningsih adalah Dosen Magister Ilmu Pemerintahan, Universitas Muhammadiyah Yogyakarta.

Zuly Qodir adalah Dosen Magister Ilmu Pemerintahan, Universitas Muhammadiyah Yogyakarta 